\title{
MONOLITHIC CONCRETE VS PRECAST CONCRETE FOR THE CONSTRUCTION OF BRIDGE BY TH CANTILEVER METHOD
}

\author{
Dumitru Daniel Morlova, Assistant Eng. UTCB - CFDP, daniel morlova@ yahoo.com \\ Corina Chiotan, Lecturer, PhD Eng. UTCB - CFDP, chiotanc@yahoo.com
}

\section{Rezumat}

În cadrul articolului cu titlul „Beton monolit versus beton prefabricat la execuţia în consolă a podurilor" vor fi abordate o serie de probleme care apar atât la proiectarea cât şi la execuţia structurilor de poduri din beton precomprimat utilizând metoda execuţiei în consolă.

Această metodă a revoluţionat podurile din beton, din punct de vedere al deschiderilor şi al uşurinţei traversării unor obstacole dificile. În afara avantajelor realizării unor structuri din beton monolit prin execuţie în consolă, utilizarea elementelor prefabricate conduce la micşorarea semnificativă a timpului de execuţie şi la diminuarea problemelor care pot apărea din cauza curgerii lente şi a contracţiei betonului.

Materialul prezentat în cadrul articolului cu titlul „Beton monolit versus beton prefabricat la execuția în consolă a podurilor" va prezenta principiul metodei de execuţie în consolă, avantajele utilizării acestei metode, cazurile particulare pentru care se pretează o astfel de structură, scheme statice şi secţiunile transversale adoptate pentru acest tip de structuri, cât şi modul de îmbinare al tronsoanelor prefabricate în funcţie de generaţia din care fac parte.

De asemenea, se va prezenta un studiu de caz în care vor fi analizate cele doua variante de execuție în consolă (turnare monolită a tronsoanelor respectiv montare de tronsoane prefabricate) și vor fi prezentate concluzii privind oportunitatea utilizării uneia dintre cele două variante.

\section{Cuvinte cheie: beton, pod, monolit, prefabricat, consolă.}

\section{Abstract}

In the article "Monolithic Concrete vs Precast Concrete for the Construction of Bridges by the Cantilever Method", there are approached a number of issues that come out in the design and execution of prestressed concrete bridge structures using the cantilever method.

This method has revolutionized concrete bridges, in terms of spans, and the ease of crossing some difficult obstacles. In addition to the advantages of making monolithic concrete structures by the cantilever method, using prefabricated elements leads to significant decrease in execution time and reducing problems that may occur due to creep and shrinkage of concrete. 
The material presented in the paper "Monolithic Concrete vs Precast Concrete for the Construction of Bridges by the Cantilever Method" shows the principle of the cantilever method, the advantages of using this method, the particular cases that are suitable for such a structure, static diagrams and cross sections adopted for this type of structures, and the way to join the prefabricated sections according to the generation they belong .

There is also presented a case study in which the two solutions are analysed (monolithical casting on site or assembling prefabricated sections) and conclusions regarding the opportunity of using one of them.

Keywords: concrete, bridge, monolith, prefabricated, cantilever.

\section{THE PRINCIPLE OF THE CANTILEVER METHOD. ADVANTAGES AND FEATURES OF THE METHOD}

Due to the definition of the cantilever method, it was registered a remarkable evolution in the design and execution of concrete bridges.

This procedure allowed the construction of bridges having static schemes (continuous beams or frames) with over $200 \mathrm{~m}$ spans.

Because of the removal of scaffoldings, this method is recommended for some particular situations [5]:

- Crossing long and high-depth valleys;

- Maintaining clearance during the entire execution period;

- In the case of high substructures.

The cantilever method principle consists in the step by step execution by assembling of cantilever sections.

The weight of the newly cast section and of the necessary equipment is supported by the previously built sections [4].

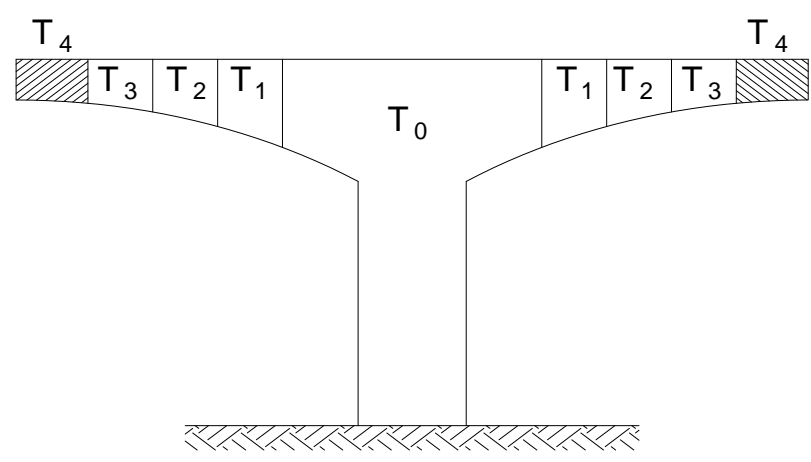

Figure 1. The principle of the cantilever method 
In the case of in-situ sections, there are used sliding forms fixed on the previous section until reaching the desired concrete class (mentioned in the design project). Further on, the newly cast section is fixed to the existing structure by introducing prestressing cables.

Precast sections are placed by a crane or by an already existing installation which was placed on the previously constructed sections (in the case of deep valleys) [1].

Construction by cantilever method of the superstructure of a bridge can start either from the piers or from the abutment. If the construction starts from the piers (figure 1), the first step is casting the base section $\left(\mathrm{T}_{0}\right)$, then symmetrically placing the adjacent sections $\left(\mathrm{T}_{1}, \mathrm{~T}_{2}, \mathrm{~T}_{3}\right.$ etc) such that the structure maintains its equilibrium [5].

For assuring the stability of the deck against asymmetric loads during execution (which are very possible), the following measures are taken:

- Temporary anchoring the superstructure into the pier;

- Temporary supporting the superstructure on piers placed in the proximity of the pier. They can be either supported by very short cantilevers or independent.

\section{STATIC SCHEMES AND TRANSVERSAL SECTIONS FOR PRESTRESSED CONCRETE BRIDGES DESIGNED BY THE CANTILEVER METHOD}

\subsection{Static schemes}

Static schemes for bridges constructed by the cantilever method are closely related to the execution procedure, in which the resulting superstructures corresponding to each execution stage are assembled into final structures either by placing hinges in the middle of spans or by continuations.

The simplest static scheme results from frame bridges - by binding with hinges cantilevers which have spans of equal length (figure 2). In this manner the length of marginal spans is equal to half of the current span's length [5].

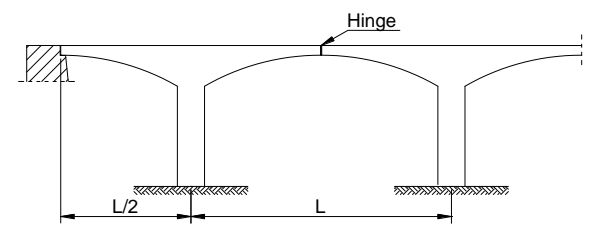

Figure 2. Cantilevers with equal length 
Static schemes of frame bridges are simple and statically determined when subjected to their self-weights and to prestressing. They become statically undetermined only after the construction of hinges between cantilevers.

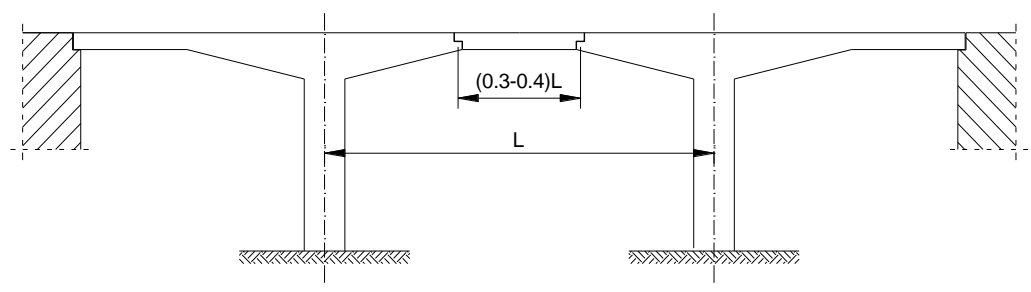

Figure 3. Frame consoles and independent bays

This solution keeps the advantages regarding the independence of efforts belonging to the structure with respect to possible settlements or rotations of substructures produced by the foundation soil. This solution also has the advantage of a favorable distribution of bending moments along the structure.

Static schemes having continuous beams or cantilevers are the most spread and used for exploitation. They are obtained by continuation of the substructures corresponding to each execution stage (figure 4).

Continuation of substructures, done by concreting a central section or by placing a closing section, removes inconveniences and the necessity of hinges in the middle of spans. The structure's continuity is advantageous related to reducing of the vertical deformations.

For example, a continuous structure having a constant deck height and a large number of equal spans will have deformations four times smaller when subjected to an uniformly distributed load than a similar structure which has hinges in the middle of spans.

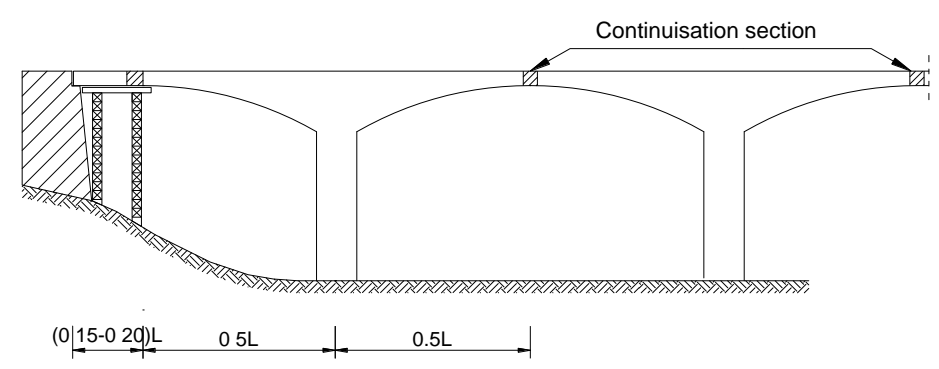

Figure 4. Continuation of substructures 
A special problem is represented by choosing the proportion between spans. Whenever possible, it is selected the solution of choosing spans with equal lengths, such that will result equal cantilevers during execution.

For marginal spans, if the deck is simple supported on abutments, it's optimal length is not equal to half of the current span's length like in the case of the cantilever method.

For example, in the case of a bridge which has three spans with scaffoldings it will be obtained an equilibrated distribution of bending moments if it's chosen a marginal span which has length 0.75-0.80 from the central span's length.

The same structure, but executed by the cantilever method, taking into account its self weight, prestressing of a statically undetermined system, the execution method of the deck near the abutment, is economically for a ratio of 0.65-0.70 between the length of the marginal span and the length of the central span.

The drawn conclusions are the same for structures which have multiple current spans. If the above ratios are taken into account, the most important advantage is that the deck will not uplift from the abutments' supports when acted by dead loads and live loads. If the marginal span is chosen such that its length is half of the intermediate span's length, the superstructure's construction is simplified, because the deck will be fully executed as a cantilever. Measures for preventing the uplift of the deck above the abutment should be taken - either by ballasting, or by anchoring the plank to the abutments.

In practice it is generally preferred to consider for the marginal span the minimum length necessary to assure a positive reaction corresponding to the abutments, for avoiding dealing with the uplift of the deck [1].

\subsection{Transversal sections}

The optimal transversal section for prestressed concrete decks constructed by the cantilever method is the coffered section [2].

This transversal section type allows the transfer of high-magnitude negative bending moments (for which it is necessary to add compression plates) to the inferior zone (figure 5).

Coffered transversal sections are recommended for both cantilevers cast on site and prefabricated cantilevers (figure 6).

During execution, a coffered deck shows a better stability when is subjected to bending and torsion, unlike a deck which has an open section. 

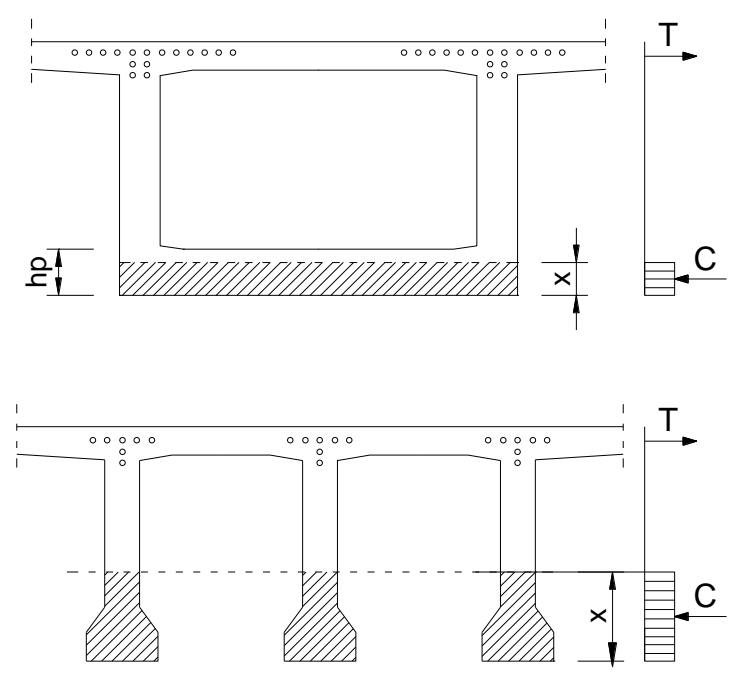

Figure 5. T section and coffered section

During exploitation, due to the high stiffness of the deck, rotations caused by eccentrical loads are small in magnitude. Because of this, transversal beams can be eliminated from the spans.
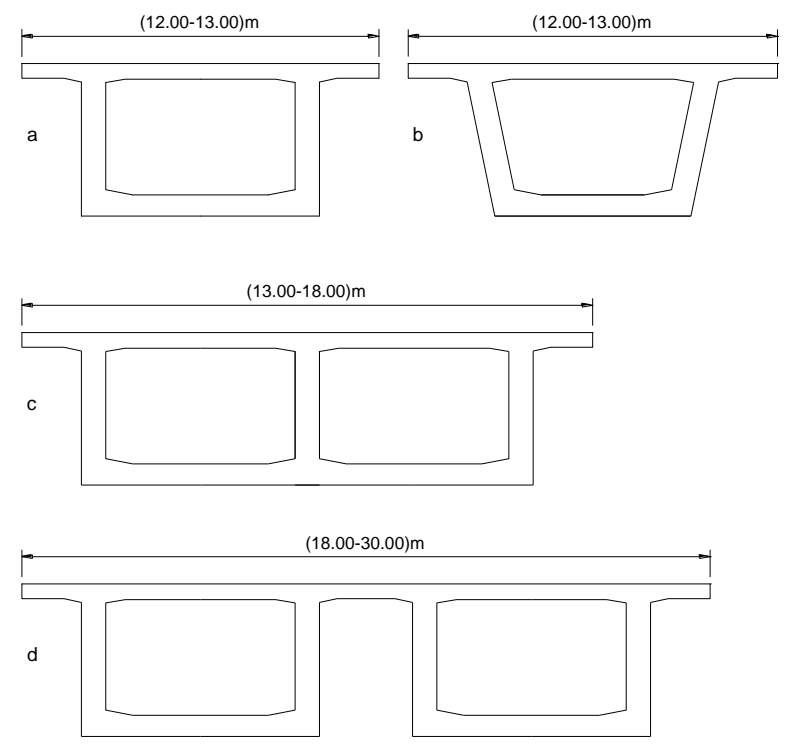

Figure 6. Recommended cross-sections for prestressed concrete decks constructed by the cantilever method

The advantages of coffered transversal sections for regions corresponding to the intermediate supports are clear. The problem is represented by keeping this type of transversal section in the regions corresponding to the middle of the spans. Theoretically, using an open transversal section and beams which have 
"T"-shape cross section would lead to material economy, but such change has some disadvantages: concentration of compression stress at the transition area between the coffered transversal section to the section with beams; lower stability for decks with long spans; necessity of intermediate transversal beams.

For bridges which have large widths the preferred solution is the one with two independent parallel decks [5].

A special category is represented by transversal sections of decks which are uniquely coffered, of which the slab has a ribbed configuration or a cellular cross-section (figure $7 \mathrm{a}, \mathrm{b}$ and $\mathrm{c}$ ). The solution shown in figure $7 \mathrm{c}$ makes possible large dimensions for the slab's cantilevers.

The plate's closed section forms voids through which hot air can pass, thus preventing appearance of the glazed frost on the sidewalk area.

a)

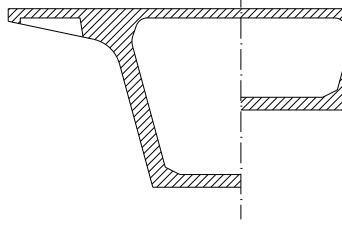

c)

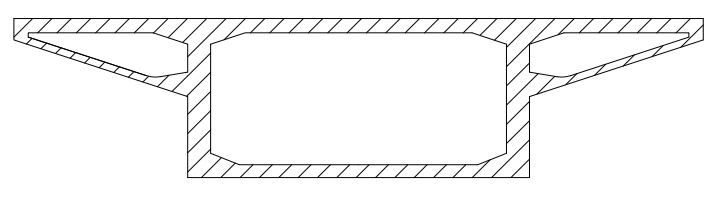

b)

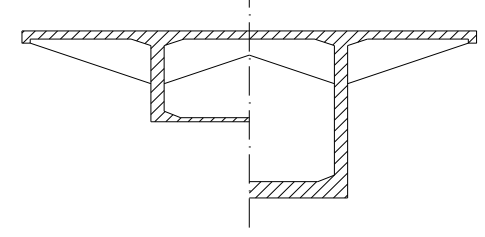

Figure 7. Cross-sections of a single cassette decks and cantilever slabs

In the case of very high bridges there are used multicoffered transversal sections, formed by two central walls and two laterally inclined walls (figure 8). This transversal section shows a high torsional stiffness and an efficient transversal distribution, especially in the case of curved bridges, for which is recommended a constant deck height.

In figure 9 it is shown a transversal section in which the central walls are vertical and there are used inclined struts for assuring the transversal section's geometry [2].

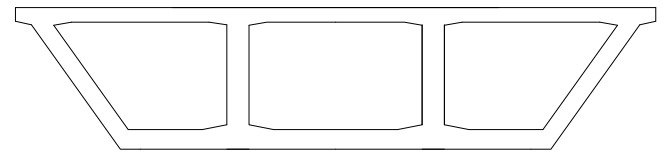

Figure 8. Multi boxes section

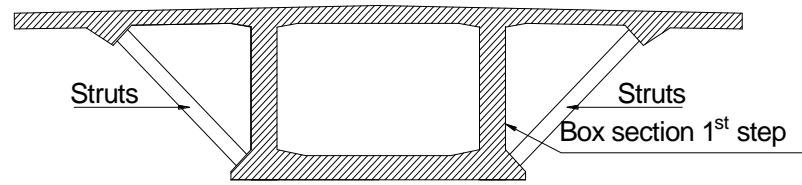

Figure 9. Section with inclined struts 


\section{JOINING PREFABRICATED SECTION}

Prefabricated elements have certain advantages from the point of view of material quality and construction period. sections.

Prefabricated sections must be joined very well to the previously mounted

Bridge sections have joining thresholds for assuring the most precise positioning of prefabricated elements, in both vertical plane and horizontal plane. These are placed in the coffer and in the superior slab and need to carry shear forces coming from the joints.

By the type of joints, bridge sections are classified in [2]:

$-1^{\text {st }}$ generation sections

$-2^{\text {nd }}$ generation sections

The $1^{\text {st }}$ generation sections have a single joint on each wall and on the superior slab (figure 10). They were the first sections used for construction by the cantilever method. In time it was proven a series of disadvantages:

- Ineffective carrying of tangential unitary stresses from the joint's cross section.

- Difficulties regarding the continuity of the unprestressed reinforcement.
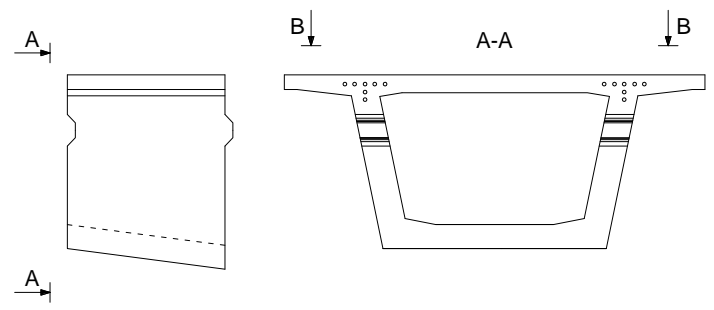

B-B

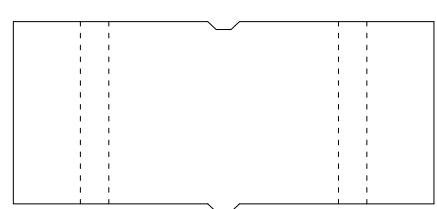

Figure 10. $1^{\text {st }}$ generation sections
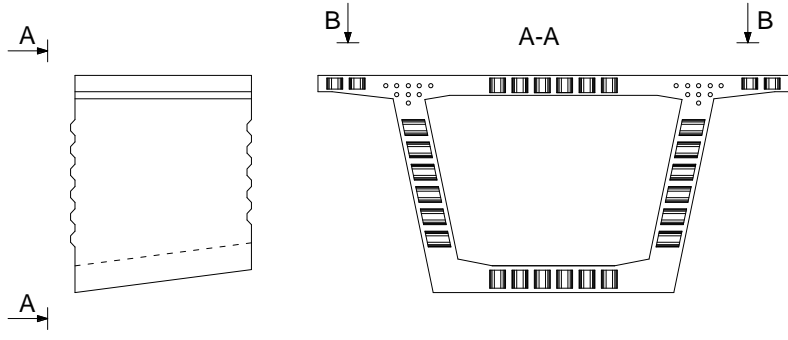

B-B

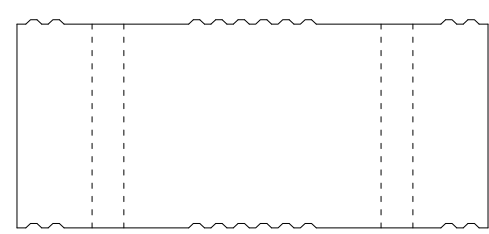

Figure 11. $2^{\text {nd }}$ generation sections

Due to experience, joining of bridge sections was improved by raising the coggins number in the coffer's wall but also in its plates $\left(2^{\text {nd }}\right.$ generation 
sections). In this manner were removed the disadvantages of the first two types of sections:

- By raising the coggins number, stresses produced by shear forces were carried more efficiently.

- Strips of cement-mortar are injected in isolated groups [5].

\section{CASE STUDY : BRIDGE ON NATIONAL ROAD 56 OVER THE JIU RIVER AT PODARI}

\subsection{Description of the structure}

The base sections from the top of the piles, have $9.52 \mathrm{~m}$ length and were prestressed before placing the prefabricated sections.

From the static point of view, the structure is a continuous (Gerber) beam, coffered, made of prestressed concrete with spans of $45.00 \mathrm{~m}+3 \times 60.00 \mathrm{~m}$ $+45.00 \mathrm{~m}=270 \mathrm{~m}$, supported on the infrastructures by supports made of steel class OT 50A (figure 12).

The total width of the structure is $10.80 \mathrm{~m}$, from which $7.80 \mathrm{~m}$ is the width of the roadway and the $3.00 \mathrm{~m}$ difference is reprezented by two sidewalks, each of $1.50 \mathrm{~m}$ width (figure 14 ).

The coffer of the superstructure has variable height, between $2.20 \mathrm{~m}$ in the middle of the spans and $3.70 \mathrm{~m}$ on the piers (figure 13). The width of the coffer is $5.50 \mathrm{~m}$. The walls of the coffer have $35 \mathrm{~cm}$ thickness, The superior slab has $25 \mathrm{~cm}$ height in the coffer's axis and the height of the inferior slab is between 20 and $45 \mathrm{~cm}$ [3].

In figure 15 is exposed bending moments diagram for the final structure in exploitation.
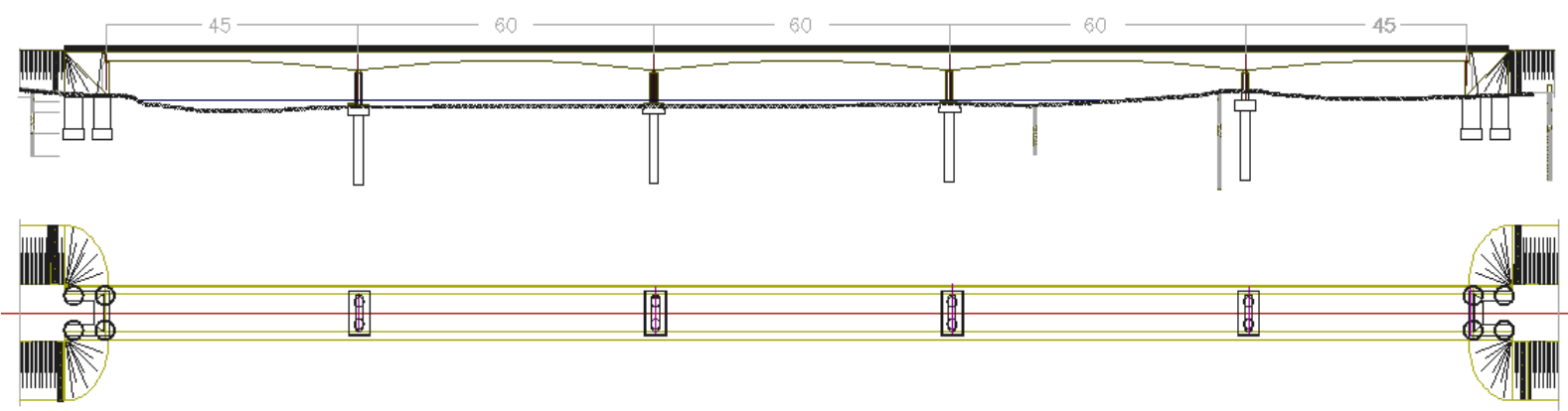

Figure 12. General disposition 
ROMANIAN JOURNAL

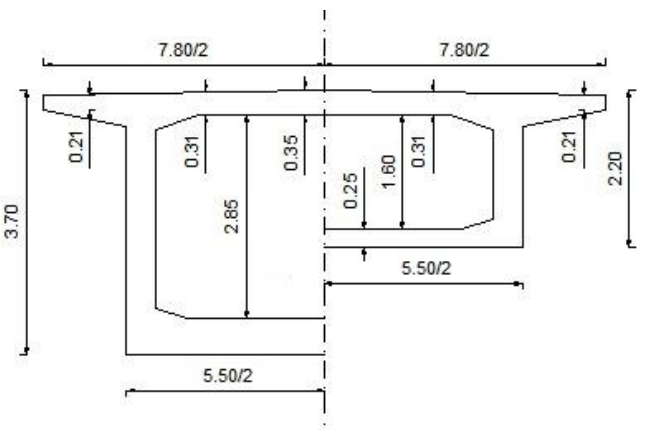

Figure 13. Cross-section of the prefabrictated sections

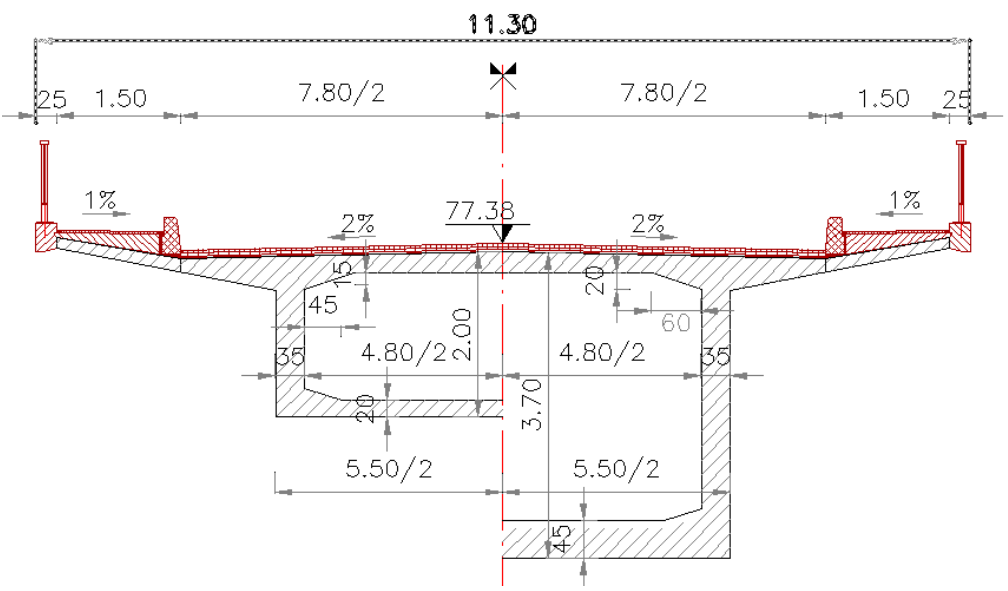

Figure 14. Cross-section of the final structure

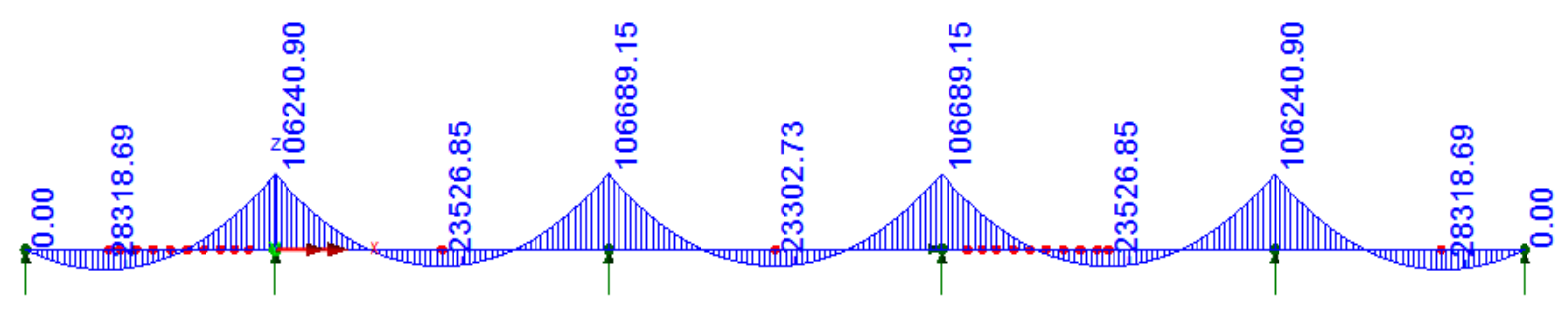

Figure 15. Bending moment diagram for the final structure subjected to $1.35 \mathrm{x}$ self-weight $+1.35 \mathrm{x}$ weight of the cantilever $+1.35 \mathrm{x}$ sidewalk $+1.35 \mathrm{x}$ border + $1.35 \times$ parapet $+1.35 \mathrm{x}$ weight of the roadway

Following are the moments obtained in the two methods of execution.

Table 1. Bending moments of the characteristic cross sections for each execution stage, in the case of prefabricated sections: $1.2 \times$ self-weight +1.2 $x$ (weight of the crane + section which is about to be placed)

\begin{tabular}{|r|r|r|r|r|r|r|r|r|r|r|}
\hline Stage & $\begin{array}{c}\text { M. pier } \\
{[\mathrm{kNm}]}\end{array}$ & $\begin{array}{r}\text { M. sect. 1 } \\
{[\mathrm{kNm}]}\end{array}$ & $\begin{array}{c}\text { M. sect.2 } \\
{[\mathrm{kNm}]}\end{array}$ & $\begin{array}{r}\text { M. sect. 3 } \\
{[\mathrm{kNm}]}\end{array}$ & $\begin{array}{c}\text { M.sect 4 } \\
{[\mathrm{kNm}]}\end{array}$ & $\begin{array}{c}\text { M. sect 5 } \\
{[\mathrm{kNm}]}\end{array}$ & $\begin{array}{c}\text { M. sect. 6 } \\
{[\mathrm{kNm}]}\end{array}$ & $\begin{array}{c}\text { M. sect7 } \\
{[\mathrm{kNm}]}\end{array}$ & $\begin{array}{c}\text { M. sect 8 } \\
{[\mathrm{kNm}]}\end{array}$ & $\begin{array}{c}\text { M. sect 9 } \\
{[\mathrm{kNm}]}\end{array}$ \\
\hline \hline $\mathbf{1}$ & 7502 & 0 & 0 & 0 & 0 & 0 & 0 & 0 & 0 & 0 \\
\hline $\mathbf{2}$ & 12310 & 3157 & 0 & 0 & 0 & 0 & 0 & 0 & 0 & 0 \\
\hline $\mathbf{3}$ & 19338 & 7375 & 3496 & 0 & 0 & 0 & 0 & 0 & 0 & 0 \\
\hline $\mathbf{4}$ & 27605 & 13022 & 7735 & 3882 & 0 & 0 & 0 & 0 & 0 & 0 \\
\hline $\mathbf{5}$ & 36812 & 19801 & 13213 & 8076 & 3618 & 0 & 0 & 0 & 0 & 0 \\
\hline $\mathbf{6}$ & 47143 & 27818 & 19981 & 13609 & 7674 & 3467 & 0 & 0 & 0 & 0 \\
\hline $\mathbf{7}$ & 58952 & 37309 & 28225 & 20620 & 13208 & 7525 & 3445 & 0 & 0 & 0 \\
\hline $\mathbf{8}$ & 72108 & 48164 & 37846 & 29020 & 20146 & 13001 & 7458 & 3415 & 0 & 0 \\
\hline $\mathbf{9}$ & 79673 & 54487 & 43496 & 34010 & 24343 & 16404 & 10070 & 5233 & 1873 & 0 \\
\hline
\end{tabular}


ROMANIAN JOURNAL

Table 2. Bending moments of the characteristic cross sections for each execution stage, in the case of monolithical casting: $1.2 \mathrm{x}$ self-weight $+1.2 \mathrm{x}$ (weight of the form + scaffolding + weight of the fresh concrete):

\begin{tabular}{|c|r|r|r|r|r|r|r|r|r|r|}
\hline Stage & $\begin{array}{c}\text { M. pier } \\
{[\mathrm{kNm}]}\end{array}$ & $\begin{array}{c}\text { M. sect. 1 } \\
{[\mathrm{kNm}]}\end{array}$ & $\begin{array}{c}\text { M. sect.2 } \\
{[\mathrm{kNm}]}\end{array}$ & $\begin{array}{c}\text { M. sect. 3 } \\
{[\mathrm{kNm}]}\end{array}$ & $\begin{array}{c}\text { M.sect 4 } \\
{[\mathrm{kNm}]}\end{array}$ & $\begin{array}{c}\text { M. sect 5 } \\
{[\mathrm{kNm}]}\end{array}$ & $\begin{array}{l}\text { M. sect. 6 } \\
{[\mathrm{kNm}]}\end{array}$ & $\begin{array}{c}\text { M. sect7 } \\
{[\mathrm{kNm}]}\end{array}$ & $\begin{array}{c}\text { M. sect 8 } \\
{[\mathrm{kNm}]}\end{array}$ & $\begin{array}{c}\text { M. sect 9 } \\
{[\mathrm{kNm}]}\end{array}$ \\
\hline \hline $\mathbf{1}$ & 9994 & 0 & 0 & 0 & 0 & 0 & 0 & 0 & 0 & 0 \\
\hline $\mathbf{2}$ & 14972 & 4351 & 0 & 0 & 0 & 0 & 0 & 0 & 0 & 0 \\
\hline $\mathbf{3}$ & 23250 & 9660 & 4905 & 0 & 0 & 0 & 0 & 0 & 0 & 0 \\
\hline $\mathbf{4}$ & 32513 & 16319 & 10165 & 5457 & 0 & 0 & 0 & 0 & 0 & 0 \\
\hline $\mathbf{5}$ & 42630 & 24042 & 16606 & 10631 & 5170 & 0 & 0 & 0 & 0 & 0 \\
\hline $\mathbf{6}$ & 54397 & 33398 & 24661 & 17400 & 10399 & 5126 & 0 & 0 & 0 & 0 \\
\hline $\mathbf{7}$ & 66651 & 43460 & 33543 & 25115 & 16718 & 10050 & 4984 & 0 & 0 & 0 \\
\hline $\mathbf{8}$ & 80564 & 55113 & 43982 & 34355 & 24521 & 16416 & 9913 & 4910 & 0 & 0 \\
\hline $\mathbf{9}$ & 96385 & 68459 & 55928 & 44922 & 33433 & 23672 & 15516 & 8858 & 3677 & 0 \\
\hline
\end{tabular}

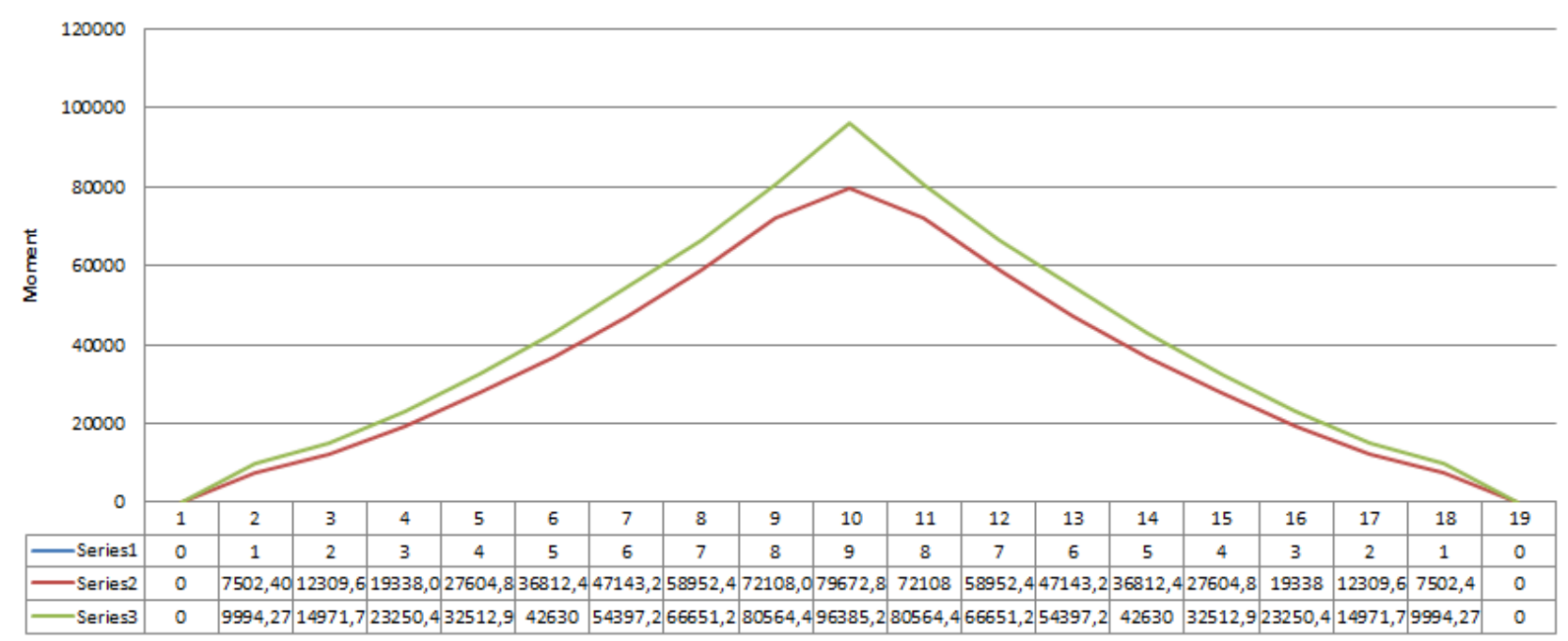

Figure 16. Bending moments monolithic version and the version with prefabricated sections

\section{CONCLUSIONS}

Bridges constructed by the cantilever method are different from bridges constructed by classical methods by severas important matters:

- Because of the removal of scaffoldings, this method is recommended for some particular situations like: crossing long and high-depth valleys or obstacles; for maintaining clearance; in the case of high infrastructures. 
- The costs of such structures are in competition with the costs of metallic structures. Metallic decks dominated for a long period of time.

- Short execution period.

More advantages appear when there are used prefabricated sections:

- Higher quality of the precast concrete;

- The prefabricated concrete elements shrink the most during the periods between casting and placing them on the structure;

- The usage of prefabricated elements decreases the execution period of a bridge superstructure - three or four prefabricated sections can be placed in one day;

- It is shown in the previous case study that bending moments which appear during the execution stage when using prefabricated sections are $15 \%$ smaller than the bending moments which appear when casting concrete on site.

To highlight the advantages regarding costs and execution period when using prefabricated sections, there are considered:

Number of prefabricated sections:

Number of monolithic sections:

Fabrication period of all sections:

Number of initial piers:

Execution period of a monolithic section:
8 - according to the case study;

2 - according to the case study;

48 days;

4 pieces;
a) 30 days;
b) 15 days;
c) 10 days;

Consider the construction done successive for each pier.

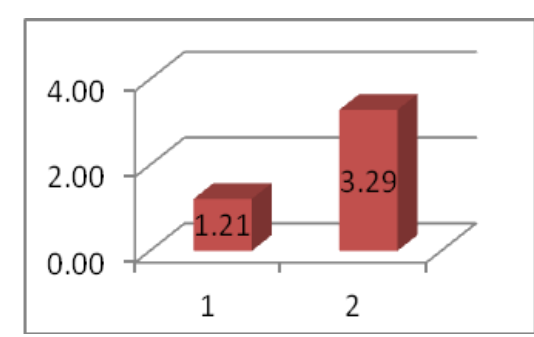

a)

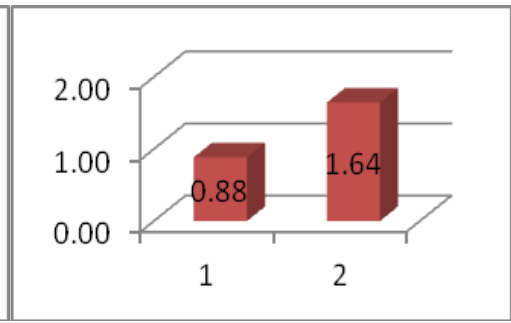

b)

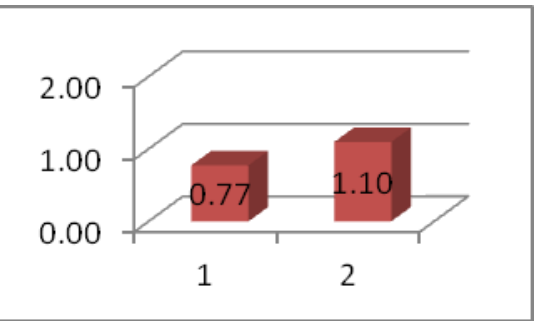

c)

The above graphs show the difference between execution time when using prefabricated elements (first column) and execution time when casting elements on site (second column).

The values from the above diagrams represent the period of time (expressed in years) in which the structure is constructed for each solution. 
Due to cement setting accelerators, the period of time in which the monolithic concrete reaches its desired class is shorter, but the costs increases, while in the case of prefabricated sections, the cost remains the same.

From the point of view of stresses (bending moments), the maximum values of the design bending moments on the supports during exploitation are 1.83 times larger than the maximum values of the bending moments which appear during execution in the case of prefabricated concrete sections and 1.51 times larger than the values of the maximum bending moments during execution in the case of monolithic sections.

Consequently, prefabrication of the elements does not ensure a material economy (prestressed reinforcement).

\section{REFERENCES}

[1]. CHIMON CAPATU: "Prestressed concrete bridges", Technical Publishing House, Bucharest, 1983;

[2]. J. MATHIVAT: "Construction par encorbellement des ponts en beton precontraint", Editions Eyrolles, Paris 1979;

[3]. PANTELIE VELEANU, TIBERIU DUMITRESCU: "Structures artworks for roads," Inedit Publishing House, Bucharest, 1998;

[4]. RADU PETRE IONEL: "Reinforced concrete bridges - special issues", Institute of Civil Engineering Bucharest, 1974;

[5]. RADU PETRE IONEL, EMIL NEGOESCU, PETRE IONESCU: "Reinforced concrete bridges" Didactic and Pedagogical Publishing House Bucharest, 1981. 